\title{
Sustainability of E-Trike as Alternative Mode of Public Transportation System: The Case of Cabanatuan City, Philippines
}

\author{
Felipe E. Balaria, Marilou P. Pascual, Mercedes D. Santos, Arjay F. Ortiz, Arneil G. Gabriel*, \\ Teodora Luz Soto Mangahas
}

Nueva Ecija University of Science \& Technology, Cabanatuan City, Philippines

Email: ^opats14@yahoo.com

How to cite this paper: Balaria, F.E., Pascual, M.P., Santos, M.D., Ortiz, A.F., Gabriel, A.G. and Mangahas, T.L.S. (2017) Sustainability of E-Trike as Alternative Mode of Public Transportation System: The Case of Cabanatuan City, Philippines. Open Journal of Civil Engineering, 7, 362-377. https://doi.org/10.4236/ojce.2017.73025

Received: May 27, 2017

Accepted: August 11, 2017

Published: August 14, 2017

Copyright $\odot 2017$ by authors and Scientific Research Publishing Inc. This work is licensed under the Creative Commons Attribution International License (CC BY 4.0).

http://creativecommons.org/licenses/by/4.0/

\begin{abstract}
The City of Cabanatuan is dubbed as the "Tricycle Capital of the Philippines". Tricycle is a three wheeled vehicle used to transport people. Cabanatuan has about 30,000 registered gas-fed four-stroke motorized tricycles. Tricycle operation in this City has become the source of livelihood for around 10,000 families. Its number has tremendously increased despite growing competition and declining net daily income and the adverse effects it brings to the environment. The study analyzed the different aspects in the adoption of E-trikes (electric tricycles) as a mode of public transport system replacing motorized tricycles in the city. The conceptual framework of sustainable development was used to analyze the data. Basic accounting method in determining return on investment and payback period were used to compare the cost and return from among the current mode of transportation as against the adoption of E-trike. Data gathering employed the interviews, survey questionnaires and focus group discussion. The three areas of sustainability measured in the study were economic, socio-political and environmental. The study showed that from among 412 tricycle driver-operators randomly selected, majority were amenable to the shift from engine propelled tricycle to E-trike. However, cost of E-trike deters adoption and full implementation by the City Government. Political issue is also the utmost consideration since work displacement is imminent among the stakeholders once adoption of this mode takes place. On the other side, E-trike was found to be sustainable in the long run both on the point of view of operators and the riding public. The paper recommended that policy regulation be laid down, adopted, and implemented by the local government unit in response to the Philippines Cleaner Air Act.
\end{abstract}

\section{Keywords}

Motorized Tricycle, Electric Tricycle, Environmental Hazard, Adoption of 
Available \& Better Technologies, Sustainability, Commercial Viability

\section{Introduction}

The use of tricycle has become the mode of transportation in most developing cities of the world [1]. Tricycle (motorized and non-motorized) is the prime mode of intra-city transportation [2] though considered as informal sector, its impact on transportation and management is beyond question [3]. In China, working tricycles continue to provide social and economic needs despite the threat of being phased out due to the neoliberal mobility developing within the city [4]. In India, the same mode of transportation is used by common people which posed a major challenge to the growing population on how the government would maintain good air quality [5]. In Nigeria, the use of motorized tricycle is encouraged within the city limits to decongest the traffic [6]. In Metro Manila, Philippines, it is the prevailing mode of transportation using secondary streets occupying the front seat in local policy making in local governance and urban development [7]. In Cabanatuan City Philippines, this mode of transportation comprises more than $50 \%$ of conveyances in view of the limited routes that jeepneys could take [8].

In the Philippines, electric tricycle or E-trike is the same as tricycle in terms of configuration or almost as similar to that of the traditional rickshaw which is three-wheeled, and can ferry several passengers and dependent on the body design and capacity of the motor engine. E-trike is run by electricity while the latter is gas-fed. A typical design popular in the Philippines is that a sidecar which is attached to the side of a motorcycle for carrying passengers.

The use of motorized tricycle is already a part of every Cabanatueno's everyday living. It is used as a mode of commuting, freight delivery system, private family service and source of income. A rough estimate made by the City Legalization Office in charge of issuing franchise to tricycle operators showed that there are 10,000 driver-operators of motorized tricycle plying daily in the city with color-coding in place. The operation of tricycle generates a daily income equivalent to P2 million pesos or roughly 40,000U\$ (at the exchange rate of $1 \mathrm{U} \$=$ P50) from the riding public. In a recent study conducted by Balaria, it was found that there is a dwindling $5 \mathrm{U} \$$ daily income in operating a tricycle compared to 10U\$ to 20U\$ per day during the last decade [9]. The study also found that Cabanatuan continued to experience increase in tricycle population due to: 1) high unemployment and absence of alternative livelihood; and 2) increase in commuting population. Despite this trend, tricycles remain to be the prime mode of transportation in the City.

The use of tricycle as a mode of transportation actually poses hazards and adverse effects on the environment [10]. Yumul quoted that about $34 \%$ of total vehicular population in the Philippines is made up of two-and three-wheelers 
which also become the major contributor to pollution and other environmental and health hazards [11] [12] The use of motorized tricycle is also identified as the source of noise and air pollution exposing the public to a greater danger of health-related problems [13]. For instance, a 2-stroke engine tricycle is known to contribute to air pollution [14] in Jakarta Indonesia. Tricycles are identified as one of the public transport systems causing excessive gas emission contributing to lead and nitrogen dioxide release in the atmosphere [15]. At present, 99\% of the Cabanatuan's tricycle population use four-stroke motor engines which generally produced higher carbon monoxide (CO); carbon dioxide(CO2), the 'greenhouse gas'; and Nitrogen Oxide (NOx), potential contributors to photochemical smog and to ozone layer depletion. According to Asian Development Bank (ADB), the Philippines' carbon dioxide emissions would nearly quadruple in less than 25 years because of automobile and motorcycle use. In view of this, several options have been laid to address the problem. The formulation and strict implementation of Philippine Clean Air Act of 1999 and the introduction of electric tricycle are among the identified solutions. Consequently, the ADB in partnership with the Department of Energy (DOE) has begun introducing the use of E-trike to the Local Government Units (LGUs) to replace the motorized tricycles. E-trike reduces carbon dioxide emissions and minimizes air pollution. It also avoids excessive fuel consumption and reduces oil dependency, and eventually increase job opportunities and tricycle drivers' income in the long run.

As part of culture and immediate source of livelihood among the residents of Cabanatuan, the change from motorized to E-tricycle is not just a mere policy issue. It affects not only those directly involved and its stakeholders, but to the whole system from planning to implementation. As of this writing the researchers have read no study conducted in Cabanatuan City, Philippines dealing specifically on the positive and negative effects of using E-trike in place of motorized tricycle. The social, political and economic impact of using electric-powered tricycle remains an unclear to most city folks. This is the gap that the study would like to address. In general, the study tried to explain the sustainability of using E-trike as a mode of public transportation in the city. It is specifically intended to:

a) Describe the tricycle industry in Cabanatuan City;

b) Describe the hazards of using four-stroke engine propelled three-wheeled tricycles to the environment and the community, and;

c) Determine the sustainability of adopting E-trike as an alternative mode of public transportation in the City and;

d) Describe the policy implication on the issue.

\section{Methodology}

The study used the descriptive method of research. The researcher used several research techniques in data gathering such as websites, documentary analysis, 
interviews, observations, and questionnaire-checklist. Convenience sampling was observed in the conduct of the interview. The study was made in 89 barangays in Cabanatuan City. Randomized block design was used to determine the sample size for the study. Hence, 412 tricycle operator-drivers were identified as the respondents. Basic accounting method for computing for the Return on Investment (ROI) was employed to compare the cost and return between the motorized one and E-trike.

\subsection{Conceptual Framework}

The study adopted the concept of sustainable development as framework of analysis leading to the proposed use of E-trike as an alternative to four-stroke engine propelled tricycle. Sustainable development as it is understood and observed is the ability of the present generation to meet their needs without sacrificing the right of the future generation to meet their own needs. The sustainable development approach consists of three main components namely; economic sustainability, environmental sustainability and socio-political sustainability [16]. The study would like to establish that the use of E-trike could change the way tricycle operators consume fossil fuels [17] and consequently change the socio-political and economic opportunities for the next generation of residents in the City. The current motorized four-stroke propelled engines of tricycles which are heavily reliant on fossil fuels. These results in greenhouse gases, which have been linked to climate change as well as negative health impacts as a result of air pollution, including smog and particulates. The environmental sustainability of E-trike is beyond a question of alternatives. The change from motorized to Etrike could eventually ensure a higher income and low maintenance cost for tricycle operators. The economic sustainability in the use of E-trike will provide economic self-sufficiency especially on the part of the operator arising from a short period Return of Investment (ROI). Finally, the socio-political sustainability rests on the assumption that economic well-being would result to greater social and political development in the families of drivers and tricycle operators. Higher standards of living and improved quality of life could trigger their desire to now finance and support the education of their children and the possible cultivation of a higher degree of political participation. The sustainability of the proposed alternative could promote higher social capital and heightened community involvement as parameters of good citizenship and community membership.

\subsection{Theoretical Framework}

The purpose of theoretical framework is to limit the scope of the study and guide in the data collection [18]. The study used David Easton's Systems approach [19] in the study of social and political life. As part of a social system, the operation of four-stroke propelled motorized tricycle affects the society as a whole, environmental and public health included. It is being used as the major means of public 
transport within the City and a source of livelihood for 9,000.00 city residents. As part of the economic and social system of the city, any change in policy involving tricycle may affect the residents which may create adverse political support and negative reaction within the sphere of the social system. In this case, it emanates from the driver-operators and the commuting public. Any policy issued by the City Council to the effect of using E-trike instead of the current motorized tricycle may strengthen or even lessen people's support to city government. On the other side, the proposed change in the mode of public transport may invite popular support or political action which may cause disturbance to the smooth functioning of the social system. Any public policy as in this case may offend or positively attract policy support. Therefore, the systems theory treats the entire social system as interlinked and interrelated such that malfunction in one subpart would create destruction or disruption of the other parts. Hence, the study is done to come up with the possible policy direction with less impact on the systems operation. From the above framework is derived the following research paradigm, to wit (Figure 1).

The research paradigm shows the interrelatedness of variables in the study [20]. This used the systems approach in the study of the sustainability of E-trike. The paradigm shows the importance of determining first the current status of the tricycle industry in Cabanatuan City including its practices and the environmental and health hazards pose by the current system i.e., gas-fed tricycle. Then follows comparing the alternatives which has the greatest benefits i.e., cost and return of an investment as this can be the influencing factor in addressing the need for a change, and finally its acceptance. Hence, the possibility on the sustainability in the adoption of E-trike can be viewed using the economic, socio-political, and environmental models so that these will the basis for a policy recommendation.

Meanwhile, the feedback section will be used as basis for improvement, and if there is a need for modification or control of a process or system by its results or effects. This is necessary in the implementation and survival of regulatory mechanisms, and thus feedback is inherent to all interactions so adjustments can be made to achieve the desired result.

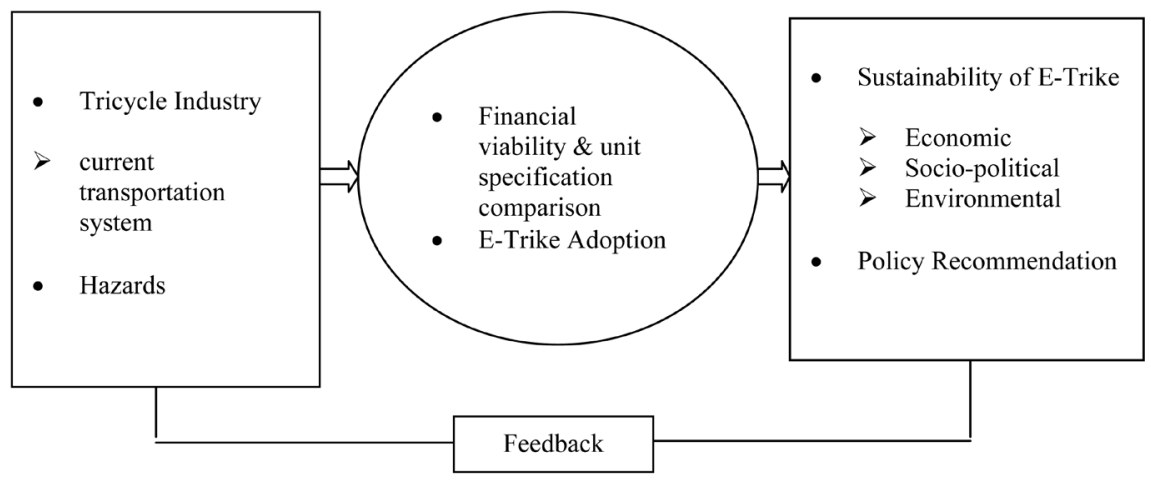

Figure 1. Research paradigm. 


\section{Results and Discussion}

\subsection{Description of the Tricycle Industry in Cabanatuan City}

The City of Cabanatuan is a first class city and the center of commerce and trade of the entire province of Nueva Ecija in the Philippines. It has a population of about 302,231 as of 2015. It has a land area of 192.29 square kilometers and categorized as first class city based on income. The city is also known as the "Tricycle Capital of the Philippines" having the greatest number of tricycles using the streets whether public or privately owned. A typical tricycle in Cabanatuan can carry 2 to 4 passengers (driver included) i.e., two passengers at the sidecar and one at the back of the driver [21]. The type of service is door-to-door. Most of the tricycles in Cabanatuan are run by four-stroke motor engines. Sidecars are improvised structure made of scrap metals. There is at present no law that regulates the size and configuration of sidecars which technically makes it a road hazard and prone to accidents. Sidecars are actually undersized for a common Filipino commuter which made it unstable and accident prone.

The mushrooming of commercial establishments, offices, and subdivisions in the city has created a demand for more tricycles. This development has triggered economic activities that have also increased employment opportunities and income among its residents. Cabanatuan has a road network which spans to a total length of 350.24 kilometers [8]. A rough estimate of $9 \%$ of the population is engaged in tricycle operation as a means of livelihood, the highest in terms of number compared to other cities in the Philippines.

The current fare for tricycle is P14 or (U\$ $0.28 \$)$ for every regular passenger for the first kilometer and additional P2 (U\$ 0.044థ) for every succeeding kilometer where the rate decreases depending on the distance and number of passenger. The recent survey made by the authors indicated that Cabanatuan imposed the highest tricycle fare in the country making the rate uncompetitive. Survey further also revealed that the income derived from this occupation is seldom sufficient for the daily needs of the respondents. The regulation of tricycles as a public mode is devolved at the local level [22]. There are numerous city ordinances on tricycle operation, and implementation of such remains under the Local Government Unit's control.

Owning a tricycle in the city would entail an investment between U\$1,200U\$ 1800 per unit. This already includes the sidecar which can be purchased between U\$180 - U\$300. Majority are financed by motorcycle companies usually made available thru monthly amortization at approximately U\$ 48 - U\$ 60 over a period of three years. Maintenance cost is estimated at $\$ 70$ annually. Current fare vis-à-vis volume of passenger daily can be translated into U\$ 7 gross income excluding the cost of gasoline at $U \$ 2-U \$ 3$, thereby giving the operator a net income of U\$ 5 .

\subsection{Hazards Motorized Tricycles Pose to the Environment}

In the study conducted in 2005 by Asian Development Bank, emission test on 
tricycles showed that hydrocarbon was at $6000 \mathrm{ppm}$ or 10 times the acceptable standards. While Cabanatuan's tricycle population comprises $90 \%$ four-stroke engines, the same ADB studies (2005) revealed that this type of motor engine may be more efficient in some ways than two-strokes, but still emits Nitrogen Oxide, Carbon Dioxide and are higher in terms of engine operating temperature. The ADB study [23] and the World Health Organization (WHO) revealed the tricycles are the major source of noise even in the presence of the mandatory law on tail pipe emission tests. This includes the hazards it pose to human health. Survey further revealed that although there were few reported accidents in the city, tricycles are more accident prone due to 1) sidecar instability, 2) reckless and abusive drivers and inferior quality of sidecar made of scrap materials. In the case of Cabanatuan, tricycles are identified as the greatest contributor to its traffic congestion since public utility vehicles are limited only to major thoroughfares. The volume of tricycles roaming the city far exceeds the city's road network. Lukewarm implementation of "no tricycle zone" along public highways has aggravated the number of accidents. Limited seating capacity also leads to unintended accidents resulting from overloading and recklessness on the part of the driver. Insufficient regulation on franchises also allows unscrupulous individuals to use tricycle who pose as legitimate tricycle operator to commit offense on passengers. Stricter regulatory policy on tricycle operation minimizes hazards caused by unregulated operation of this public utility vehicle.

\subsection{Sustainability of E-Trike}

The ADB in partnership with the Department of Energy (DOE) initially presented 5 units of E-trike to the city government of Cabanatuan on July 2013. As planned, E-trike would operate like mini jeepney on selected routes, and would directly compete with local public utility vehicles (PUVs). As observed by the researchers, there was a mixed reaction from the riding public as regard E-trike replacing motorized engine tricycles-neither were they excited nor curious about its capacity and configuration. Random interviews with the commuters signified a more positive acceptance on this proposed LGU project, but opined that the fare would be uncompetitive since it was patterned after the present fare matrix that of motorized tricycles. Following E-trike's proposed rate of P8-P10 (U\$ 0.16\$ - U\$ 0.20\$) per passenger made the observers apprehensive about its economic viability to driver-operator-investor. Respondents also doubted if there would be savings in the commuter's transportation cost, and estimated to incur only additional cost because of limited routes. Noticeable also was the visible resentment from PUV operators when the pilot run was tested. E-trike's structure is made of bioplastic material. It consists of parts such as windshields, dashboards, side mirrors and handlebars with body structure similar to jeepneys. E-trikes can also load up to ten passengers including the driver and its design can be customized. 


\subsection{Economic Sustainability}

Once a shift to E- trike is implemented, there will also be a shift in the demand for the services, spareparts providers, sidecar manufacturers and technicians. However, there is a looming doubt among operators on whether the resolution to change from motorized tricycle to E-trike would be passed by the LGU. In the same survey, operator-respondents indicated that unemployment would be unavoidable. They also doubted if there is any reduction in fuel consumption because the initiative only covered the tricycle subsector and did not include other vehicles. The tricycle transport service in Cabanatuan remains to be the primary source of income in the absence of employment opportunities. Inversely, the negative impact that E-trike may bring can be compensated through employment opportunities creation when E-trike providers come in. The experiences of Mandaluyong City (2011) proved to have high acceptance rate both on the E-trike operators and the commuting public. Similarly, performance of E-trike outweighed the conventional tricycles in terms of speed. In terms of capital outlay, there is an apprehension on the part of driver-operators whether they can afford the price of E-trike. The unit introduced by Asian Development Bank would cost the investor between P180, 000 - P200, 000+ (U\$ 3600 - U\$ 4000+) per unit. Some foreign investors are just as interested and willing to manufacture and finance this project. In part too, this can be facilitated by the Local Government Unit (LGU) with the support from creditors and guaranteed by the Philippine Government, and the willingness of private sector to invest and partner with stakeholders. Initially, $A D B$ is providing $U \$ 300$ million loan for this project. One of the proposed financing terms would be the lease-to-own agreement scheme. Nevertheless, the apparent disadvantage in the shift from E-trike to motorized tricycle would mean a loss of job and income for most of the tricycle operators. In some cities in the Philippines E-trike operators have reported a greater take-home pay of between $16 \$$ to $20 \$$ per day.

\subsection{Unit Specification, Financial Viability and Maintenance Cost Compared}

In terms of passenger capacity, E-trike can carry up to 9 passengers as against 4 for motorized. The lead battery type is used in the four-stroke engine type, while lithium rechargeable battery is used in the former. While motorized tricycles use gasoline, E-trike battery charges on electricity which costs motorists P11.00 (U\$ 0.22థ) per kwh. Therefore, for every kilometer use for motorized tricycle, there is a cost of P1.20 (U\$ $0.024 \Phi)$ of gasoline and P0.30 (U\$ 0.006థ) electricity for E-trike. A gasoline savings of P0.90 (U\$ 0.018థ) for E-trike is identified (Table 1).

Apparently, E-trike is every aspect is more advantageous in terms of fuel savings, while doubling the number the passengers it can carry (Table 2).

Since this technology is practically new in the market, the cost of lithium battery is estimated to cost U\$ 120 with an estimated useful life of 3 years. The cost 
Table 1. Comparative specifications and passenger capacity of motorized versus E-Trike.

\begin{tabular}{ccc}
\hline \multirow{2}{*}{ Particulars } & \multicolumn{2}{c}{ Type of Vehicle } \\
\cline { 2 - 3 } & Motorized & E-Trike \\
\hline Passenger Capacity & 4 & 9 \\
Battery & lead & lithium \\
Kilometrage & 60 to 80 & 40 to 80 \\
Gasoline Use Liter/s & 1.20 & - \\
Charging Time Hour/s Electricity & - & 1 to 12 \\
Cost of per Liter & P 50.00 & - \\
Cost per kWh & - & P 11.00 \\
Cost per Km. Use & P 1.20 & P 0.30 \\
Savings per Km. & - & P 0.90 \\
\hline
\end{tabular}

Exchange Rate Computation U\$ 1 = P 50.

Table 2. Financial viability analysis. ( $1^{\text {st }}$ year of operation).

\begin{tabular}{ccc}
\hline \multirow{2}{*}{ Particulars } & \multicolumn{2}{c}{ Type of Vehicle } \\
\cline { 2 - 3 } A. Profit \& Loss & Motorized & E-Trike \\
\hline Service Income @ P14 fare per passenger & P 144,000 & P 306,000 \\
Less: Operational Cost & & \\
Daily Gas P104 @ 365 days & 37,960 & - \\
Daily Electricity P55 @ 365 days & - & 20,075 \\
Spareparts Replacement ${ }^{*}$ (lump sum) & 4000 & 2000 \\
Battery Expense & 2000 & 6000 \\
Membership Fees & 750 & 750 \\
Registration, other fees & 4000 & 4000 \\
Total & 48,750 & 32,825 \\
Income & 92,250 & 273,176 \\
ROI (Income/Investment) & & 200,000 \\
Bnvestment & 90,000 & $137 \%$ \\
\hline Return of Investment (ROI) & $103 \%$ & \\
\hline
\end{tabular}

*Payments summed up to a single transaction. Notes: Since vehicle replacement parts vary in price and can be broken down into several units, averaging can be computed without distorting the actual value.

of spare parts and service can be projected at U\$ 80 annually for motorized and U\$ 40 for E-trike, respectively.

It can be noted that under the motorized type, data gathered was based on industry experience. Assumptions underlying financial projections were made for E-trike because of its newness in the market, but conservative estimates were 
made to come up to a more realistic figure. For example, P92,250 (U\$ 1,845) service income for motorized tricycle was arrived at by dividing that amount by P14 (U\$ 0.28\$) per passenger per travel, and divide again to 365 (days in a year) can be translated into 28 rides per day. Similarly, the P273, 176 (U\$ 5,463.52) service income from e-trike was assumed at 7 travels per day based on 10-passenger capacity per travel at P14 (U\$ $0.28 థ)$ fare rate per passenger. The income P92, 250 (U\$ 1,845) and P273, 176 (U\$ 5,463.52) for the motorized and E-trike, respectively further reveal a P250 (U\$ 5) and P748 (U\$ 14.96) revenues daily. Return on investment, on the other hand, implies that investment on both can be recouped in less than a year. Note that $100 \%$ (ROI) is equivalent to one (1) year. The higher the percentage, the lesser is the time to recoup the investment.

\subsection{Social and Political Sustainability}

An informant from the City Government of Cabanatuan disclosed that a change in public transportation could be possible through a city ordinance since tricycle operation had been devolved to the local government. But there are many factors to consider like: the 1) alternative source of livelihood for those who would be displaced, 2) cost per unit of E-trike, 3) availability of credit facilities and the limited capacity of the operators to transact with lending institutions which in most cases require collateral unless government-guaranteed, and 4) the willingness of private businesses to venture or partner with the government to promote E-trike. Accordingly, it was advised that shifting from engine propelled motorcycle to E-trike could only be possible after 5 to 10 years.

The local legislative body is the Sanggunian (vernacular and legal term for "council") which is one of the branches of Local Government Unit who performs the crucial role of providing policies necessary for local development [22]. The inaction of the Sanggunian would mean economic retrogression, while its action could bring about genuine countryside development. The Sanggunian as a collegial body could create an effective local governance responsive to the demands of the people [24]. The power to remove and withdraw franchise for tricycle operation in the city is also lodged with the Sanggunian [25]. It is also within the power of the Sanggunian to order the change from motorized tricycle to E-trike as an attribute of its "general welfare function" [26].

The use of E-trike indicates acceptability both to operators and the riding public. Of the 412 tricycle operator-respondents interviewed, 243 are amenable to change in the city's transportation system, 128 are not knowledgeable, 105 implied lack of resources to purchase E-trike, while 97 are complacent or showed no interest on the issue. Random interviews made during the initial test run of E-trike in Cabanatuan showed that there is a high acceptability on the use of E-trike. In fact, 24 out of 41 commuting respondents said that they are agreeable to the use of E-trike. Majority or 32 of them doubted that the proposed fare 
would be competitive. The City has an increasing population at $2 \%$ growth annually and development of commercial centers could further create demand for transportation especially for tricycles.

The tricycle industry in Cabanatuan City still and will remain to be a viable source of livelihood for the City residents. The City government controls the issuance of franchise to allow ordinary residents to engage in public utility business. The drivers and operators remain a potent source of votes for politicians. Hence, public demands for the change from motorized tricycle to E-trike can strike a good policy direction. The negative effect, however is the cost of production of E-trike which amounts to almost P200, 000 (U\$ 4,000) or 3 times the amount of motorized tricycle. This is the area where possible government and private sector partnership may enter into the picture. The private sector may collaborate with the local government unit to finance the manufacturing of E-trike. This partnership arrangement is sanctioned by the 1991 Local Government Code of the Philippines [27]. The manufacturing of new side car would also create additional jobs for the city residents leading to the increase of per capita income of the city. This is in addition to the increase in real income for the 30,000 registered tricycle operators resulting from the decrease in maintenance cost of electric tricycle or E-trike compared to motorized tricycle. The political importance of the issue would generate political support to the local government by providing public policy that is responsive to the social and political demands of the commuting public and the driver-operators consisting of more than 80,000 families and members. The political support to the change in favor of Etrike is overwhelming except in terms of the cost of the unit where the driver-operator must put up capital that he never anticipated. The local government therefore may transform the public demand into a policy while subsidizing the unit in part or in whole as a form financial assistance especially during the early stage of policy implementation. The availability of improved \& innovative mass transportation system will also help commuters and the economy as a whole. Essentially, this will pave the way for new inventions and discoveries. Its use is also a signal on the willingness of the residents to embrace new technology while mitigating the harmful effects to the environment of the motorized tricycle.

\subsection{Environmental Sustainability}

The City of Cabanatuan is known for being one of a few warmest cities in the Philippines during summer season. There are only two seasons in the Philippines i.e., rainy and summer seasons. The warmest temperature experienced by the city every summer is attributed not only to its geographical location but also of the gas emissions created by nearly 30,000 tricycles operating in the city. As part of the central plain of Luzon surrounded by mountain ranges where hot climate temperature is locked within the plain and engulfed by mountain ranges from escaping towards the Pacific Ocean. Aside from the hot temperature, gas emission and its particulates from motorized tricycle engine combustion con- 
tribute even more to the warming of the city. The annual estimates for the 9000 tricycles plying daily on Cabanatuan's streets would mean a gasoline consumption of 4.3 million liters a year. As the Philippines is a net importer of energy, the increasing transportation needs become costly over time. In effect, E-trike will reduce carbon dioxide emissions and air pollution, avoid fuel cost and reduce oil dependency. Meanwhile, ADB report disclosed that E-trikes are anticipated to reduce annual carbon dioxide emissions by approximately $2,600,000$ tons. The issue on the use of E-trike goes with it the issue on alternative livelihood for $9 \%$ of the population of Cabanatuan who rely on tricycle driving as source of income and the need of the riding public. In some other context, New York City is now gearing towards green deliveries where freight tricycles powered by electricity charged batteries move within the city to deliver goods and commodities. The City sees numerous advantages such as environment friendly, limited parking space required, decongestion of major roads in the City and short period of travel time.

The use of E-trike was introduced to the public in an environment friendly vehicle campaign in the Philippines in 2012. There are 623 types of electric vehicles (EV) tried and demonstrated in many LGUs in the country. The E-vehicle program is one of the government's initiative towards sustainable, energy efficient and low carbon transport future. The DOE launched in January 2012 its "Bright Now! Do Right. Be Bright. Go E-trike!" designs an electric tricycle contest to encourage and promote designs of the Philippine version of "Green Vehicle". Vehicular emissions including tricycles lower air quality. Many solutions to the problem have been identified like planting of trees along the roadside to contain deadly gas emissions of vehicles specifically during peak hours [28]. The Philippine government launched several programs designed to lessen the impact of the use of vehicles on air pollution. The National Gas Vehicle Program for Public Transport, under Executive Order No. 290, aims to promote the use of natural gas as a clean alternative fuel for transport systems such as buses, jeepneys, taxis and other public utility vehicles. Among the various modes of transport that caught up with this program are taxis. Another program is a joint project with the Asian Development Bank (ADB), commonly known as the E-trike project. This project replaces 100,000 gasoline-fueled tricycles with electric tricycles (E-trikes) by 2017. The project shall be supported financially by ADB through a $\$ 300$ million loan [23]. E-trike has a quieter engine, lesser moving parts, cheaper operating costs, has no tailpipe emissions, and runs on electricity. The mainstream use of electric jeepneys/tricycles would yield beneficial impacts toward reducing oil dependence and improved air quality [29]. In an experiment conducted in London, 6 electric tricycles and 3 electric vans delivered the cargo from the distribution center to final customers. The operation of these electric vehicles did not result in any fossil fuel consumption or greenhouse gas emissions because the electricity used by these electric vehicles was produced from renewable sources. The result showed great benefits: total dis- 
tance travelled was reduced by $20 \%$ and the CO2 emissions per parcel fell by $54 \%$ [30]. The design of E-trike also provides solution to traffic congestion. The main causes of congestion are poor driving habits, poor road network, inadequate road capacity, lack of parking facilities and design of motor vehicles load capacity [31]. An adult tricycle is comprised of a standard conventional adult tricycle and a double occupancy child seat connected with the operator's portion of the vehicle. The seating capacity is 3 passengers and one driver [32]. The prevailing $\mathrm{E}$-trike design in the market can load up to 9 passengers including the driver. This means that one E-trike is comparable to 2 two motorized tricycles. This also would mean a decongestion of the major streets in Cabanatuan City. The traffic decongestion would also mean less fuel consumption and less travel time and mobility which could be computed in terms of economic valuation. The traffic decongestion would also mean less gas emission that may destroy the ozone layer.

\subsection{Policy Implication}

The clamor for the use of E-trike has not ripened into actionable popular demand. The demand for the local government to shift from fuel powered tricycle to electricity charged battery may attract political support from the tricycle operators and the public. This however must be supported by intense demands to deserve political action and reach the agenda setting of the local city council. The sector that is bound to benefit from the policy must logically steer the issue so that it reaches the attention of policy maker and may prioritize it for policy formulation. In reality, there are issues that are potential subject of policy formulation that have not even reached the stage of agenda setting for the failure of the proponents to sustain the necessary political and social actions. The policy process is basically a unity between political and administrative actions. Thus, lobbying, influence peddling, petition making, legislative and executive pressure groups are but few means to push an issue to the stage of policy formulation. But as the study showed, there is not enough reason for the city council to prioritize the issue despite the financial assistance offered by the ADB. There are multifarious issues that an LGU faces. All these need priority legislative actions and local resources that are finite and limited. Thus, for the issue to reach policy formulation phase, enough social and political pressures are necessary. The policy on using E-trike does not require extra ordinary political will for the local legislature to respond accordingly to the public demand and public choice. It is both politically sustainable and socially acceptable. It only requires sufficient clamor from the people of having a stake and whose interests are only dependent on tricycle operation. The local legislative body reacts naturally to any political and social demands. But such demands must be pressing and sufficient to drive the initiative of the local legislative policy making machineries and transform these demands into a public policy. Unfortunately, the issue on the use of E-trike has not even reached policy formulation stage. 


\section{Conclusion/Recommendation}

\subsection{Conclusion}

Many Cabanatuenos rely on tricycle driving as a source of livelihood. The study showed that despite declining income attributed to tricycle operation; it remains to be the primary source of income for most of its residents. Although the current transportation system uses the four-stroke motorcycle engine which is more environment-friendly than the traditional two-sttroke, it is not totally safe because the gas particulates it emits that causes global warming other than the hazards it poses to public health. Comparative study on the unit's specification reveals that E-trike is more efficient in terms of body design as it is safer, less fuel consumption and almost double in passenger capacity. Although capital outlay for E-trike is more than twice than that of the conventional tricycle, return on investment on the former can be recouped in a shorter period of time. Resistance to the change in the mode is divided among its stakeholders because of job displacement, prohibitive cost of the unit and lack of credit facilities despite $\mathrm{ADB}$ offered assistance. The adoption of E-trike is in the long run and sustainable in terms of economic, socio-political and environmental impact. The change in the mode of transportation has more advantages because it does not use fossil fuel, increases income of the operator and has a greater socio-political impact. The LGU legislation of E-trike adoption is nil in the near future because of political pressures since majority of stakeholders belong to voting masses.

\subsection{Recommendation}

The study showed the need to further understand the effects, advantages and disadvantages as regard this planned change in the mode of public transportation system. The limitation of the study is the lack of data available specifically dealing with the efficiency of E-trike to replace the conventional tricycle. Proper information dissemination may be needed focused more on its advantages and its economic and environmental sustainability. The City government may also consider a proactive stance on the issue to implement mandatory orientation of tricycle operators on the possible change from motorized to E-trike and develop programs such as other sources of livelihood for the tricycle operators who would be displaced by this change, and for them to take the initiative and support the Clean Air Act by establishing mechanism and structures supportive on the use of E-trike.

\section{References}

[1] Guillen, M.D.V., Ishida, H., Okamoto, N. and Tsutsumi, M. (2007) Public Transport Policies and the Road-based Public Transport Service in Developing Countries: The Case of Indigenous Public Transport Modes in Davao City, Philippines. The 7 th International Conference of Eastern Asia Society for Transportation Studies, Tsukuba, 2007, 18.

[2] Vergel, K.B. (1992) Exploratory Study on the Adoption of Traffic Impact Fee in the 
Philippines Francis F. Villareal Master of Science in Civil Engineering (Transportation Engineering). University of the Philippines, Quezon City.

[3] Guillen, M.D.V. and Ishida, H. (2004) Motorcycle-Propelled Public Transport and Local Policy Development: The Case of "Tricycles" and "Habal-habal" in Davao City Philippines. IATSS Research, 28, 56-66.

https://doi.org/10.1016/S0386-1112(14)60092-3

[4] Norcliffe, G. (2011) Neoliberal Mobility and Its Discontents: Working Tricycles in China's Cities. City Culture and Society, 2, 235-242. https://doi.org/10.1016/j.ccs.2011.11.006

[5] Kokaz, K. and Rogers, P. (2002) Urban Transportation Planning for Air Quality Management: Case Study in Delhi, India, Of Role of Social and Economic Costs in Welfare Maximization of Mobility Choice. Transportation Research Record Journal of the Transportation Research Board, 1817, 42-49. https://doi.org/10.3141/1817-06

[6] Taofeek, G.K. and Afolabi, O.J. (2005) An Assessment of Motorcycle Operation in Ado-Odo Ota Local Government Area of Ogun State. https://scholar.google.com.ph/

[7] Manasan, R.G. and Mercado, R.G. (1999) Governance and Urban Development: Case study of Metro Manila. Philippine Institute for Development Studies, Makati.

[8] City Government of Cabanatuan (2012) City Planning and Development Office. City Government of Cabanatuan, Cabanatuan City.

[9] Balaria, F.E. (2012) The Tricycle Industry in Cabanatuan City. Unpublished Master's Thesis, Nueva Ecija University of Science and Technology, Cabanatuan City.

[10] Li, F., Hu, D., Zhou, C., Wei, C. and Cheng, Z. (2011) Factor Analysis of Grievous Road Traffic Accidents in China. 11 th International Conference of Chinese Transportation Professionals (ICCTP): Towards Sustainable Transportation Systems, Nanjing, 14-17 August 2011, 1966-1977. https://doi.org/10.1061/41186(421)195

[11] Prevention, K.I. (1998) 53-Year-Old Dies in Tricycle Tractor Overturn While Transporting Round Bale. Morbidity and Mortality Weekly Report, 44, 26.

[12] Boquet, Y. (2015) Metro Manila's Challenges: Flooding, Housing and Mobility. In: Singh, R.B., Ed., Urban Development Challenges, Risks and Resilience in Asian Mega Cities, Springer, Berlin, 447-468. https://doi.org/10.1007/978-4-431-55043-3 23

[13] Amistad, F.T. and Regidor, J.R.F. (2005) Traffic Management in a City with UN World Heritage Site. Journal of East Asia Society Studies. 6, 2291-2306.

[14] Potera, C. (2004) Air Pollution: Asia's Two-Stroke Engine Dilemma. Environmental Health Perspectives, 112, A613. https://doi.org/10.1289/ehp.112-a613a

[15] Tri-Tugaswatil, A., Suzuki, S., Kiryu, Y. and Kawada, T. (1995) Automotive Air Pollution in Jakarta with Special Emphasis on Lead, Particulate, and Nitrogen Dioxide. Journal of Human Ecology, 61, 261-275. https://doi.org/10.3861/jshhe.61.261

[16] Brown, B.J., Hanson, M.E., Liverman, D.M. and Merideth, R.W. (1987) Global Sustainability: Toward Definition. Environmental Management, 11, 713-719. https://doi.org/10.1007/BF01867238

[17] Browne, M., Allen, J. and Leonardi, J. (2011) Evaluating the Use of an Urban Consolidation Centre and Electric Vehicles in Central London. IATSS Research, 35, 1-6. https://doi.org/10.1016/j.iatssr.2011.06.002

[18] Miles, M.B. and Huberman, A.M. (1994) Qualitative Data Analysis: A Methods Sourcebook. SAGE Publications, Thousand Oaks, California. 
[19] Easton, D. (1957) An Approach to the Analysis of Political Systems. World Politics, 9, 383-400. https://doi.org/10.2307/2008920

[20] Belen, A. (2010) Thesis Writing Primer. Rex Bookstore, Manila Philippines.

[21] Luansing, R., Pesigan, C. and Rustico, E. (2015) An E-Trike ICE Project-Innovative, Concrete and Ergonomic: Systems Design to Support Sustainable E-Trike Commercialization. Procedia Manufacturing, 3, 2333-2340. https://doi.org/10.1016/j.promfg.2015.07.380

[22] Congress of the Philippines (1991) The Local Government Code of 1991 Republic Act 7160. Batasan Complex Commonwealth Avenue. Congress of the Philippines, Quezon City.

[23] Asian Development Bank (2012) Air and Noise Pollution Reduction from Tricycles, Asian Development Bank, Manila, Philippines.

[24] Gabriel, A.G. and Gutierrez, M.P. (2017) Praxis in Local Legislative Governance: Measure of Organizational Effectiveness of the Component Cities in Nueva Ecija, Philippines. Asia Pacific Journal of Multidisciplinary Research, 5, 12-20.

[25] Turner, M. (1999) Philippines: From Centralism to Localism. In: Turner, M., Ed., Central-Local Relations in Asia-Pacific, Springer, Berlin, 97-122. https://doi.org/10.1007/978-1-349-27711-7 5

[26] Jr. Brillantes, A.B. (1998) Decentralized Democratic Governance under the Local Government Code. A Governmental Perspective, Manila.

[27] Akintoye, A., Hardcastle, C., Beck, M., Chinyio, E. and Asenova, D. (2003) Achieving Best Value in Private Finance Initiative Project Procurement. Construction Management and Economics, 21, 461-470. https://doi.org/10.1080/0144619032000087285

[28] Okon, I.E. (2015) Assesment of Vehicular Emissions on Air Quality and Proximate Composition of Amaranthus Hybridus and Mangifera Indicain in Zaria Nigeria. Amahdo Bello University, Zaria.

[29] Nacino, J.M.R. (2014) Energy Security and Sustainable Transport: The Future of Jeepneys in the Philippines. The University of Tokyo, Tokyo.

[30] Saénz Esteruelas, J.M. (2016) An Evaluation of the Environmental Impact Reduction in the Urban Delivery Logistics Using Tricycles: A Case Study in Portland, OR, USA. http://academica-e.unavarra.es/handle/2454/20108

[31] Ukpata, J.O. and Etika, A.A. (2012) Traffic Congestion in Major Cities of Nigeria. International Journal of Engineering and Technology, 2, 1433-1438.

[32] Jinks, C.A. (1999) Adult Tricycle for Carrying Passengers. US Patent No. 5863058. 
Submit or recommend next manuscript to SCIRP and we will provide best service for you:

Accepting pre-submission inquiries through Email, Facebook, LinkedIn, Twitter, etc. A wide selection of journals (inclusive of 9 subjects, more than 200 journals)

Providing 24-hour high-quality service

User-friendly online submission system

Fair and swift peer-review system

Efficient typesetting and proofreading procedure

Display of the result of downloads and visits, as well as the number of cited articles Maximum dissemination of your research work

Submit your manuscript at: http://papersubmission.scirp.org/

Or contact ojce@scirp.org 